\title{
Physical and psychiatric comorbidity among patients with severe mental illness as seen in Uganda
}

Richard Stephen Mpango ${ }^{1,2,9}$, Wilber Ssembajjwe ${ }^{1,3}$, Godfrey Zari Rukundo ${ }^{4}$, Carol Birungi ${ }^{7}$, Allan Kalungi ${ }^{1}$, Kenneth D. Gadow ${ }^{5}$, Vikram Patel ${ }^{6}$, Moffat Nyirenda ${ }^{1,8,}$ Eugene Kinyanda ${ }^{1,7}$

${ }^{1}$ Mental Health Section, MRC/UVRI and LSHTM Uganda Research Unit \& Senior Wellcome Trust Fellowship, Entebbe, Uganda

${ }^{2}$ Butabika National Psychiatric Hospital, Kampala, Uganda

${ }^{3}$ Statistical Section, MRC/UVRI and LSHTM Uganda Research Unit, Entebbe, Uganda

${ }^{4}$ Department of Psychiatry, Mbarara University of Science and Technology, Uganda

${ }^{5}$ Department of Psychiatry, Stony Brook University, Stony Brook, New York

${ }^{6}$ Department of Global Health and Social Medicine, Harvard Medical School, Massachusetts, USA

${ }^{7}$ Department of Psychiatry, College of Health Sciences, Makerere University, Kampala, Uganda

${ }^{8}$ Global Non-Communicable Diseases (NCD) Section, MRC/UVRI and LSHTM Uganda Research Unit, Entebbe, Uganda

${ }^{9}$ Deartment of Mental Health, School of Health Sciences, Soroti University, Soroti, Uganda

\section{Corresponding author:}

Richard Stephen Mpango, Mental Health Project, MRC/UVRI and LSHTM Uganda Research Unit, Entebbe, Uganda. P. O. Box 49 Entebbe, Uganda.

Email:Richard.Mpango@mrcuganda.org_\& $\underline{\text { richmpan@gmail.com }}$

\section{Co-authors:}

- Wilber Ssembajjwe, Statistical Section, MRC/UVRI and LSHTM Uganda Research Unit, Entebbe, Uganda. P. O. Box 49 Entebbe, Uganda.

E mail: Wilber.Ssembajjwe@mrcuganda.org

- Godfrey Zari Rukundo, Department of Psychiatry, Mbarara University of Science and Technology, P. O. Box 1410, Mbarara, Uganda

E mail: grukundo@must.ac.ug 
medRxiv preprint doi: https://doi.org/10.1101/2020.11.04.20225813; this version posted November 6, 2020. The copyright holder for this preprint (which was not certified by peer review) is the author/funder, who has granted medRxiv a license to display the preprint in perpetuity.

All rights reserved. No reuse allowed without permission.

- Kenneth D. Gadow, Department of Psychiatry, Health Sciences Centre, Stony Brook University, Stony Brook, NY 11794-8790. Tel: 631-638-1549 FAX: 631-632-3703, E mail: kenneth.gadow@ stonybrook.edu

- Allan Kalungi, Mental Health Project, MRC/UVRI and LSHTM Uganda Research Unit, Entebbe, Uganda. P. O. Box 49 Entebbe, Uganda.

E mail: allankalungi1@gmail.com

- Carol Birungi Mugabi, Department of Psychiatry, Makerere College of Health Sciences, Uganda.

E mail: carolmugabi@yahoo.com

- Vikram Patel, Department of Global Health and Social Medicine, Harvard Medical School, Massachusetts, USA

E mail: Vikram_Patel@hms.harvard.edu

- Eugene Kinyanda, Head of the Mental Health Section, MRC/UVRI and LSHTM Uganda Research Unit \& Senior Wellcome Trust Fellow, Entebbe Uganda \& Department of Psychiatry, Makerere College of Health Sciences. Tel; 0788461950,

Email: ekinyanda@hotmail.com \& Eugene.kinyanda@mrcuganda.org

- Moffat Nyirenda is the Theme Lead for Global Non-Communicable Diseases (NCD) at the MRC/UVRI and London School of Hygiene and Tropical Medicine (LSHTM) Uganda Research unit

E mail: Moffat.Nyirenda@LSHTM.ac.uk \& Moffat.Nyirenda@mrcuganda.org 
medRxiv preprint doi: https://doi.org/10.1101/2020.11.04.20225813; this version posted November 6, 2020. The copyright holder for this preprint (which was not certified by peer review) is the author/funder, who has granted medRxiv a license to display the preprint in perpetuity.

All rights reserved. No reuse allowed without permission.

\section{Abstract}

This study established the prevalence of physical and psychiatric comorbidity and associated risk factors among 1,201 out-patients with severe mental illness (SMI) attending Butabika and Masaka hospitals in Uganda. Participants completed an assessment battery; structured, standardized and locally translated instruments. SMIs were established using the MINI International Neuropsychiatric Interview version 7.2. We used logistic regression to determine the association between physical and psychiatric comorbidity and risk factors. Prevalence of physical and psychiatric comorbidity was $13.1 \%$. Childhood sexual abuse (aOR 1.06, 95\% CI $1.03-1.10, \mathrm{P}=0.001)$, sexual abuse in adulthood (aOR 2.22, 95\% CI $1.60-3.08, \mathrm{P}<0.001)$, childhood physical abuse (aOR 1.07, 95\% CI 1.03 - 1.10, $\mathrm{P}<0.001)$ and physical abuse in adulthood (aOR 1.69, 95\% CI $1.30-2.20, \mathrm{P}<0.001)$ were associated with an increased risk of having comorbid psychiatric and physical disorders. Emerging healthcare models in Uganda should optimise care for people with physical and psychiatric comorbidity. 


\section{Introduction}

Mental ill health is a major cause of morbidity and mortality globally, with low- and middleincome countries (LMIC) experiencing a rapidly increasing prevalence of morbidity (1). Patients with severe mental illness (SMI) such as schizophrenia, depression and bipolar affective disorder die younger compared to the general population (2-4). However, most of the increased mortality among people with SMI is attributed to comorbidity with other non-communicable diseases (NCDs) $(2,3,5)$. Patients with SMI experience a range of chronic physical health problems which may interfere with quality of life, increase health seeking behaviour and contribute to poor treatment outcomes (6). In turn, mental illness contributes to the NCD risks and outcomes, through adoption of harmful behaviours (such as sedentariness, smoking or excessive alcohol intake) which may affect treatment adherence and retention in care (1). Secondly, some medications for SMI, particularly the second-generation antipsychotics are associated with increased risk of obesity, diabetes and metabolic syndrome (7). Lastly, there is a tendency for comorbidity among the severe mental illnesses; there is an increased risk for the development of depression among patients with schizophrenia (8-10); the overlap in the symptoms and genetic risk factors between psychiatric disorders suggests a common etiological mechanism (8).

Physical and psychiatric comorbidity has become increasingly important among people with SMI receiving mental health services at hospitals due to several risk factors (11). Patients with comorbidity are therefore generally thought to have higher rates of healthcare utilisation and poorer outcomes, in part because they are at risk of receiving suboptimal care for the co-existing conditions $(12,13)$. On the other hand, comorbidity may provide an opportunity for patients to receive care beyond the index condition $(14,15)$. This is best illustrated in HIV care in sub- 
medRxiv preprint doi: https://doi.org/10.1101/2020.11.04.20225813; this version posted November 6, 2020. The copyright holder for this preprint (which was not certified by peer review) is the author/funder, who has granted medRxiv a license to display the preprint in perpetuity.

All rights reserved. No reuse allowed without permission.

Saharan Africa where the control of hypertension and other NCDs is better among HIV positive than HIV negative individuals, perhaps because individuals living with HIV have more regular and intensive contact with the healthcare system $(16,17)$.

Although comorbidity is of worldwide concern, the majority of evidence to date comes from high-income countries, with only a few studies from LMIC, and fewer from sub-Saharan Africa $(1,18)$. These limited data suggest a high and increasing burden of comorbidity $(18,19)$, affecting relatively young people (20). Detection and management of mental and physical comorbidity will pose a particular challenge for LMIC healthcare systems, which historically have separated services for mental and physical health $(1,21)$. The purpose of our study was to establish the prevalence of comorbidity, associated risk factors and negative outcomes among patients with severe mental illness (SMI) in rural and urban Uganda.

\section{Results}

\section{Characteristics of study participants}

\section{Insert Table1}

Table 1, of the 1201 participants enrolled into this study, 39.7\% were between 35 and 49 years and $32.1 \%$ were between 25 and 34 years; mean age (with standard deviation) was 37.6(11.7). The urban and rural study sites contributed $58 \%$ and $42 \%$ of participants respectively. About a third each of the participants were single $(38.7 \%)$ or married $(32.0 \%)$ and a quarter $(24.6 \%)$ separated/divorced, with $4.7 \%$ widowed. Males and females enrolled in the study were $46 \%$ and $54 \%$ respectively. Christians were $81 \%$ and Muslims were $18 \%$. More than half $(57.2 \%)$ of the respondents had at least seven years of formal education. A third (32.9\%) had suffered 
medRxiv preprint doi: https://doi.org/10.1101/2020.11.04.20225813; this version posted November 6, 2020. The copyright holder for this preprint (which was not certified by peer review) is the author/funder, who has granted medRxiv a license to display the preprint in perpetuity.

All rights reserved. No reuse allowed without permission.

childhood physical abuse and a quarter $(24.7 \%)$ childhood sexual abuse. Physical abuse in adulthood was reported by $34.1 \%$, while sexual abuse in adulthood was reported by $21.9 \%$. About two thirds $(61.0 \%)$ reported a family history of psychiatric disorder.

\section{Pattern of psychiatric and physical comorbidity}

Table 2: Pattern of psychiatric and physical comorbidities among respondents

\begin{tabular}{|c|c|c|c|}
\hline Factor & Level & $\mathrm{N}=1201$ & Prevalence $(95 \%$ CI $)$ \\
\hline \multicolumn{4}{|l|}{ Primary psychiatric diagnosis } \\
\hline Schizophrenia & Yes & 320 & $26.6 \%$ \\
\hline Bipolar affective disorder & Yes & 797 & $66.4 \%$ \\
\hline \multicolumn{4}{|l|}{$\begin{array}{l}\text { Comorbid physical disorder/ } \\
\text { problem }\end{array}$} \\
\hline HIV/AIDS & Positive & $87 / 1057$ & $8.2 \%(6.7 \%-10.0 \%)$ \\
\hline Syphilis & Positive & $53 / 1095$ & $4.8 \%(3.7 \%-6.3 \%)$ \\
\hline Hypertension & Sys $>=140$ dia $>=90$ & $326 / 1201$ & $27.1 \%(24.7 \%-29.7 \%)$ \\
\hline Obesity & $\mathrm{BMI}>=30$ & $165 / 1193$ & $13.8 \%(11.9 \%-15.9 \%)$ \\
\hline $\begin{array}{l}\text { Had at least one comorbid physical } \\
\text { disorder/problem }\end{array}$ & Yes & $512 / 1201$ & $42.6 \%(39.8 \%-45.4 \%)$ \\
\hline $\begin{array}{l}\text { Had at least two comorbid physical } \\
\text { disorder/problem }\end{array}$ & Yes & $109 / 1201$ & $9.1 \%(7.5 \%-10.8 \%)$ \\
\hline \multicolumn{4}{|l|}{$\begin{array}{l}\text { Current psychiatric episode \& } \\
\text { comorbidity }\end{array}$} \\
\hline Manic episode & Yes & $74 / 1196$ & $6.2 \%(4.8 \%-7.6 \%)$ \\
\hline Psychotic episode & Yes & $263 / 1187$ & $22.2 \%(20.0 \%-24.8 \%)$ \\
\hline Depressive episode & Yes & $160 / 1189$ & $13.5 \%(11.5 \%-15.4 \%)$ \\
\hline $\begin{array}{l}\text { Did not meet criteria for at least one } \\
\text { current psychiatric disorder episode }\end{array}$ & Yes & $831 / 1201$ & $69.1 \%(66.5 \%-71.7 \%)$ \\
\hline $\begin{array}{l}\text { At least one physical and one } \\
\text { psychiatric comorbidity }\end{array}$ & Yes & $157 / 1201$ & $13.1 \%(11.3 \%-15.1 \%)$ \\
\hline $\begin{array}{l}\text { Had at least two current psychiatric } \\
\text { disorder episodes }\end{array}$ & Yes & $109 / 1201$ & $9.1 \%(7.5 \%-10.8 \%)$ \\
\hline
\end{tabular}

Table 2, bipolar affective disorder was the most prevalent (66.4\%) primary psychiatric diagnoses followed by schizophrenia (26.6\%) and recurrent major depressive disorder (7.0\%). Psychosis was the most prevalent (22.2\%) current psychiatric episode followed by depressive episode 
medRxiv preprint doi: https://doi.org/10.1101/2020.11.04.20225813; this version posted November 6, 2020. The copyright holder for this preprint (which was not certified by peer review) is the author/funder, who has granted medRxiv a license to display the preprint in perpetuity.

All rights reserved. No reuse allowed without permission.

(13.5\%) and manic episode (6.2\%). Psychiatric comorbidity was reported by $9.1 \%$ of respondents, while physical disorder/problems comorbidity was reported by $42.6 \%$. The specific comorbid physical disorder/problems were, $27.1 \%$ hypertension, $13.8 \%$ obesity, $8.2 \%$ HIV/AIDS and $4.8 \%$ syphilis.

\section{Factors associated with psychiatric and physical comorbidity}

\section{Insert Table 3}

Table 3 and 4, risk factors for psychiatric comorbidity were: age category of 25-34 years compared to those aged between 18-24 years, increasing mental health stigma, childhood physical abuse, childhood sexual abuse, physical abuse in adulthood, sexual abuse in adulthood and use of mood stabilisers. Protective factors against psychiatric comorbidity included rural residence (compared to urban residence) and increasing social support. Risk factors of HIV comorbidity were female gender and being widowed and separated (compared to being married). Being Moslem (compared to being Christian), increasing socio-economic status and having a past psychotic episode were protective against HIV.

\section{Insert Table 4}

The risk factor for syphilis comorbidity were increasing age, being widowed and separated and alcohol use. The risk factors of hypertension comorbidity were increasing age and alcohol use, while rural residence was protective against hypertension. Risk factors for obesity were female gender, increasing age, increasing socio-economic status, use of mood stabilisers, problem 
medRxiv preprint doi: https://doi.org/10.1101/2020.11.04.20225813; this version posted November 6, 2020. The copyright holder for this preprint (which was not certified by peer review) is the author/funder, who has granted medRxiv a license to display the preprint in perpetuity.

All rights reserved. No reuse allowed without permission.

alcohol drinking, use of marijuana and use of Khat, while staying in a rural residence was protective.

Association between psychiatric and physical comorbidity with negative behavioural and clinical outcomes

\section{Insert Table 5}

Table 5, only psychiatric comorbidity was associated with the negative outcomes of life time attempted suicide and risky sexual behaviour. None of the physical disorders/problems was associated with the investigated negative behavioural and clinical outcomes.

\section{Discussion}

This study demonstrates a high prevalence of physical and psychiatric comorbidity, associated risk factors and negative outcomes among patients with severe mental illness (SMI) attending out-patients' departments (OPD) at Butabika and Masaka hospitals in Uganda. According to this

study, comorbidity between psychiatric disorders and a physical disorders was reported by 13.1 $\%$ of the respondents, while a meta-analysis established the pooled prevalence of $36.6 \%$ for psychiatric disorders in patients with chronic physical diseases (22). Obviously, difference between prevalence rates established by this study (cross-sectional at baseline) and the metaanalysis by Daré et al (22) relate to the different study designs. Similarly, the prevalence of psychiatric disorders in people with chronic physical diseases living in developing and emerging countries is comparable to those in developed countries (22). Importantly, the relationship between medical and psychiatric illness involves multiple factors (23), and happens to be bi- 
directional; physical illness can cause the mental illness but also the mental illness can cause the physical illness (24). The co-occurrence of psychiatric and physical disorders is supported by the mind-body interaction (substance dualism) suggested by Descartes (1641) as described by Nadler S \& Morris K (1997) (25).

The prevalence of psychiatric comorbidity (presence of at least two current psychiatric disorder episodes) reported in this study was $9.1 \%$, which was much lower than the $24 \%$ of respondents who met the criteria for two psychiatric disorders in a study about the prevalence of psychiatric disorders on the general wards of Mbarara regional referral hospital in Southwestern Uganda; both studies used the Mini International Neuropsychiatric Interview (MINI) to determine specific psychiatric diagnoses but this study interviewed participants attending out-patient departments (OPDs), while the study by Rukundo et al. (2013)(23) interviewed admitted patients. The degree of psychiatric morbidity happens to be directly related to indicators of family adversity, physical abuse, other psychosocial variables (26), and interpersonal adversity experienced since childhood (27). Similarly, poverty, homelessness, substance use, and smoking all augment the risk of both physical and psychiatric illness (24).

Psychiatric comorbidities are so common and might be integral to schizophrenia (28).

Commonly, the symptomatology of schizophrenia over-shadows other psychiatric disorders thus it is difficult to determine primacy but the alternative approach adopted by Diagnostic and Statistical Manual of Mental Disorders (DSM-IV R) is to consider these symptoms as part of another axis I diagnosis that occurs alongside schizophrenia (29). Possibly, depressive symptoms in schizophrenia are associated with antipsychotic medications that produce neurological side effects like Parkinsonism (particularly bradykinesia, diminution of affective 
expression, masked facies, and verbal delays) and akathitic restlessness that may be confused with the psychomotor retardation or agitation of depression (28). Antipsychotic drugs may also produce a primary dysphoria, possibly due to dopamine blockade in reward pathways, and it has even been suggested that these drugs are innately depressogenic (28). Similarly, the classic construct of depression in schizophrenia is that of post-psychotic depression (PPD), defined in an appendix of the DSM-IV R (29), as a major depressive episode that is superimposed on, and occurs only during the residual phase of schizophrenia. Traditionally, depression in schizophrenia has been formulated as a psychological reaction to loss or to the psychological trauma of the psychotic episode (28). Arguably, depression is a reaction to psychosis, or represents an unmasking effect of the depression as the psychosis remits (28). Similarly, there is a clear substantial comorbidity index between bipolar disorder and schizophrenia $(30,31)$.

On the individual physical comorbidities, this study reported a rate for HIV co-morbidity of 8.2\% against a national general population prevalence of HIV of 5.7\%(32). Two earlier Ugandan studies reported higher rates of HIV co-morbidity among patients with SMI, a rate of $18.4 \%$ in 2011(33) and a rate of $11.3 \%$ in 2013 (34), this was against a national general population prevalence of HIV of $7.3 \%(35,36)$. In all these three studies, the rate of HIV among patients with SMI was generally higher than that in the general population, suggesting that patients with SMI were at increased vulnerability to HIV compared to the general population. In this study, the least reported physical comorbidity, was syphilis at a rate of $4.8 \%$, against a Uganda national prevalence rate of $2.9 \%$ in 2016 among women attending antenatal care (37). The rate of syphilis comorbidity in this Ugandan study was twice that reported in a Brazilian study (1.1\%) a country where the general prevalence of syphilis is reported at $7.7 \%$ among women attending antenatal 
care (38). Both vulnerability to HIV and syphilis which are predominantly transmitted through heterosexual relationships in the SMI context in Uganda are underlined by a common vulnerability to risky sexual behaviour and sex violence which Lundberg and colleagues (2015) in their Ugandan study reported to be more prevalent in SMI than in the general population (39). In this study, the most prevalent comorbidity reported was hypertension $(27.1 \%)$, this was against a Uganda general population rate of hypertension of $26.4 \%$ (40). This rate of comorbid hypertension in SMI is much higher than that reported by two earlier UK studies, a rate of $19 \%$ in 2014 (41) and a rate of $18.3 \%$ in 2015 (42) against a general population rate of hypertension in the UK of $26.2 \%$ in 2017 (43).

The prevalence of comorbid obesity in this study was $13.4 \%$, this is against a Uganda general population rate of obesity of $7 \%$ (44). A study among patients with SMI in the USA published in 2010 reported a rate of obesity of $52 \%$ (45), against a general population rate of $35.7 \%$ in the USA in 2009-2010 (46). Factors underlying the association between SMI and the cardiovascular risk factors of hypertension and obesity include a variety of lifestyle factors such as smoking, lack of physical activity, and poor diet (45).

The presence of psychiatric disorders in medically ill patients increases the cost of health care due to repeated ineffective use of services, increased length of hospital stay, hospitalization rates and mortality (23). It is for this reason that the World Health Organization recommended the integration of mental health services into general health care services (47), in order to effectively and efficiently respond to the psychiatric and physical comorbidity (22).

Pattern of psychiatric and physical comorbidities among patients with severe mental illness in

\section{Uganda}


The clustering of psychiatric disorders (with participants having two or more current psychiatric disorders), relates to previous literature which suggests that chronic physical, infectious and mental health conditions commonly co-exist $(1,48)$. A previous study established that psychiatric conditions (such as schizophrenia, depression, bipolar affective disorders, etc.) cluster with a range of physical NCDs as well as with chronic infections such as HIV (12). In addition to ageing, increased prevalence of comorbidity among people in low- and middleincome countries (LMICs) relates to a growing prevalence of NCDs (such as an increase in obesity and physical inactivity) in addition to the well-known burden of infectious diseases like HIV/AIDS (48). This change in condition patterns reveals the changing lifestyle, cultural behaviours, changing environmental exposures, urbanization, and healthcare-related advances that contribute to an increased prevalence of chronic conditions $(49,50)$. The relationship between mental health and physical conditions appears to be bidirectional and may arise due to shared biological factors, or mediated by various lifestyle and treatment specific factors (12). Similarly, the clustering of physical comorbidity with index psychiatric disorders was high because comorbidity is generally higher among mentally sick people who happen to be more vulnerable, socioeconomically disadvantaged, often have a lower capacity to access healthcare and deal with the burden of ill health $(48,51)$. Relatedly, some studies have found that those with comorbidity (especially those on antipsychotic treatment) are at particular risk of adverse drug events (52) and are at risk of receiving suboptimal care for co-existing physical conditions $(12,13)$. Conditions appear to cluster in many LMICs in which HIV infection is common and the use of ART widespread (49). It has been established that use of antiretroviral therapies (ART) for the treatment of HIV has been associated with insulin resistance, elevated blood lipids, and central fat accumulation, each of which can ultimately contribute to the development 
medRxiv preprint doi: https://doi.org/10.1101/2020.11.04.20225813; this version posted November 6, 2020. The copyright holder for this preprint (which was not certified by peer review) is the author/funder, who has granted medRxiv a license to display the preprint in perpetuity.

All rights reserved. No reuse allowed without permission.

of type 2 diabetes and cardiovascular diseases (48). Depression has also been shown to increase the risk of morbidity and mortality in populations with type 2 diabetes (53). Some psychotropic medications, most notably antipsychotics, have also been reported to be associated with increased risk of several physical conditions including obesity, diabetes, cardiovascular diseases, and haematological diseases $(54,55)$. It has also been suggested that chronic inflammation and oxidative stress may underlie a number of other chronic conditions and cancers, and could therefore also contribute to several comorbidity clusters (56-59). Given the common cooccurrence of mental and physical health conditions in the context of comorbidity, there is a need for better evidence about causality and confounding in order to identify the exacerbatory effects of medications on those with comorbidity.

\section{Association between socio-demographic factors and comorbid psychiatric and physical}

\section{disorders}

Relatedly, a growing body of evidence suggests that physical illnesses and multimorbidities are significantly more prevalent in the population of psychiatric patients than in the general population because mental disorders are associated with an increased risk of a wide range of chronic physical illnesses and comorbidity (60). According to this study, staying at Masaka was a protective by $23 \%$ against psychiatric comorbidity and the findings are in agreement with results from a previous study which suggests that living in rural areas is significantly associated with lower risk of reporting severe mental illnesses and happens to be associated with better overall mental health (61). Result from this study indicate that the age category of $>=50$ was protective by $39 \%$ against psychiatric comorbidity, yet other studies suggest that increasing age is associated with increased comorbidity $(62,63)$; possible explanation could be that increased 
social support (often attained with increasing age) buffers psychological distress and happens to be protective against psychiatric comorbidity (64).

Based upon results from this study, being a female increased the risk of having HIV by almost three-times and the findings happen to be in agreement with a previous study which suggests that gender disparities put women at an increased risk of $\operatorname{HIV}(65,66)$; gender inequity is manifested in the social and economic burden women carry in relation to men (66). Related to findings from this study, a recent Ugandan report (2017) indicated that in the age category of 15-64years, HIV was more prevalent among females (7.6\%) as compared to males (4.7\%)(67). Similarly, higher HIV prevalence rates among females as compared to males could be due to other socio-cultural factors $(66,68)$. Being a moslem was protective by $69 \%$ against $\mathrm{HIV}$ (aOR $0.31,95 \%$ CI 0.13 $0.72, P=0.007)$; the findings from this study are in agreement with previous studies which suggest the efficacy of male circumcision (mostly practiced by moslems) in reducing the risk of acquiring HIV and some sexually transmitted infections (69-71). Increase in social economic status (indicated by ses score) was a protective by $13 \%$ against HIV; these finding are in agreement with a previous study which suggested an association between social economic status and HIV $(68,72)$. Marital status (being single) was protective by $28 \%$ against HIV, thus happens to be in agreement with findings from a study undertaken in Kenya which established that the risk of acquiring HIV was significantly associated with being married, divorced/separated/widowed (73).

The age category of $>=50$ had a five-fold increased risk of having syphilis and the results happen to be in agreement with a study undertaken in Brazil (developing country) which suggests that the prevalence of syphilis among people with SMI ranges between $1.1 \%$ to $7.6 \%$ (74). Similar to findings from this study, a recent survey in Uganda revealed that the prevalence of active 
syphilis infection among people with HIV in the age category of 15-64 years was similar (2\%) among men and women (67). Similarly, marital status (being single) was protective by $19 \%$ against syphilis ; a related study established that concurrent sexual partners are associated with an increased prevalence of syphilis (75).

Results from this study indicates that staying at Masaka was a protective by $36 \%$ against hypertension, which happens to be in agreement with results from a recent survey with findings indicating that hypertension is mostly common among people living in the urban compared to those in rural areas due to the differences in lifestyles $(76,77)$. The age category of $>=50$ had four-fold increased risk of hypertension and these findings happen to agree with results from a study which suggests that the increasing age is a risk factor for hypertension among people with SMI (78).

Staying at Masaka was a protective by $57 \%$ against obesity which happens to be in agreement with results from a recent survey with findings indicating that obesity is mostly common among people living in the urban compared to those in rural areas due to the differences in lifestyles (76, 77). Similarly, being female had a five-fold increased risk of having obesity; a previous study suggested that sex differences in gene expression are related to antipsychotic induced weight gain (AIWG); biological processes are involved in AIWG and provide additional evidence of the genetic links between weight gain and antipsychotic treatment (79). Findings from this study are in agreement with a previous study which suggests that hypertension and obesity happens to be more common among women than men (77) due to biological, socio economic factors and gender differences in the roles. Related to findings from this study, recent surveys indicated that females had a higher prevalence of obesity than males (females $7.5 \%$; males $1.8 \%)(40,76)$. According to this study, people with SMI in the age category of $>=50$ had a four-fold increased 
risk of obesity; emerging evidence suggests that the most significant cause of weight gain relates to the metabolic side effects of antipsychotic medication (80). Probably, the increased risk of obesity among people with SMI in the age category of $>=50$ could be a result of ageing, years spent on antipsychotic treatment, coupled with the sedentary behaviour (1). Interestingly, increase in social economic status was a risk factor for obesity and these findings happen to be in agreement with previous studies undertaken in the region $(81,82)$.

\section{Psychosocial and psychiatric factors associated with comorbid psychiatric and physical}

\section{disorders}

According to this study, social support was protective by $2 \%$ against psychiatric comorbidity since social support acts as a buffer against psychological distress (64), thus a supportive social environment increases the survival of people with chronic illnesses (83). Mental health stigma was a risk factor for psychiatric comorbidity which rhymes with findings from other studies which suggest that social stigma is common among people with psychiatric comorbidity and increases as more insight is regained (84) ; social stigma is largely related to the double burden of symptoms and pressure to undertake treatment for both their mental and physical diseases, questionable prognosis and the likely associated negative outcomes (85). History of childhood physical abuse was a risk factor for psychiatric comorbidity; findings from this study are in agreement with previous studies which suggests that there is an association between self-reported childhood difficulties and later comorbidity in adulthood $(86,87)$. The high level of childhood physical abuse relates to the disciplinary measures and corporal punishment widely used in Uganda as a form of parenting, with much uncertainty as to whether they are beneficial for discipline or risk factors for mental Illness $(88,89)$; childhood physical abuse is significantly 
associated with later mental distress (90). History of childhood sexual abuse was a risk factor for psychiatric comorbidity; findings from this study happen to be in agreement with previous studies $(86,87)$. Previous studies in Uganda have reported high levels of sexual abuse commonly experienced by girls $(89,91)$, which happens to be a risk factor for poor mental health (91). Previous studies established that childhood sexual abuse is associated with increased odds of using physical violence against people (91), a higher prevalence of any mental distress (90), but may be a risk factor for 'sexual risk behaviours' in persons with SMI $(92,93)$. Similarly, physical abuse in adulthood was a risk factor for psychiatric comorbidity, while sexual abuse in adulthood had a two-fold increased risk of having psychiatric comorbidity; findings are in agreement with previous studies which established that people with mental disabilities are subjected to abuse and neglect that exacerbates their illness (94-96). Results from this study indicate that mood stabilizers were associated with psychiatric comorbidity since they are commonly used to treat people with bipolar disorder, sometimes schizoaffective disorder and borderline personality disorder; in some cases, mood stabilizers are used to supplement other medications, such as antidepressants used to treat depression. However, a previous study suggests that psychotic features and other psychiatric disorders are associated with poor treatment response to mood stabilizers in some psychiatric patients (97). A previous study established that mood stabilizers, are associated with an increased risk for several physical diseases, including obesity, dyslipidemia, diabetes mellitus, thyroid disorders, hyponatremia; cardiovascular, respiratory tract, gastrointestinal, haematological, musculoskeletal and renal diseases, as well as movement and seizure disorders (98).

Among the psychiatric illness factors, having experienced a past psychotic episode was protective against HIV and the plausible explanation relates to the social stigma expressed 
towards the mentally sick people that could have limited their sexual involvement thus reduced risk for contracting HIV $(84,85)$.

Among the maladaptive behaviours, alcohol use had a two-fold increased risk of having syphilis; results from this study are in agreement with previous studies which suggest that there is a high correlation between alcohol use and sexually-transmitted diseases (STDs) because alcohol use strongly influences men and women to engage in risky activities while under the influence (99, 100). Alcohol subjects the user(s) into 'a state of higher confidence and lower inhibition', leading them to make riskier choices, like engaging in unprotected sexual activities (100).

Alcohol use was a risk factor for having hypertension; results from this study happen to be in agreement with findings from previous studies which established that alcohol use is widely recognized and a highly prevalent risk factor for hypertension which is supported by biochemical pathways $(101,102)$.

According to results from this study, mood stabilizers were associated with a two-fold increased risk of having obesity. Results from this study rhyme with findings established through review of studies which suggest that treatment with mood stabilisers is associated with overweight and obesity which results from excessive carbohydrate consumption, coupled with reduced physical exercises - common among patients with comorbidity (103). Alcohol drinking problems were associated with a ten-fold increased risk of obesity and the results are in agreement with a Ugandan study which suggests that frequent alcohol use (highly prevalent in Uganda) is a key risk factor for both hypertension and obesity (104). Similarly, use of marijuana was associated with eight times increased risk of having of obesity, contrary to findings from a study which suggests a lower prevalence of overweight and obesity among young adult cannabis users (105, 106); possible explanation could be that cannabis consumption reduces energy storage and 
medRxiv preprint doi: https://doi.org/10.1101/2020.11.04.20225813; this version posted November 6, 2020. The copyright holder for this preprint (which was not certified by peer review) is the author/funder, who has granted medRxiv a license to display the preprint in perpetuity.

All rights reserved. No reuse allowed without permission.

increases metabolic rates, thus reversing the impact on body mass index of elevated dietary omega-6/omega-3 ratios (107). Use of khat was thirty-seven times associated with an increased risk of having obesity; evidence from recent review of the studies suggests that different khat extracts or cathinone produces changes in terms of weight, fat mass, appetite, lipid biochemistry and hormonal levels (108). The same review further suggests that the mechanism of these changes is the central action that produces changes in the physiology of dopamine and serotonin (108).

\section{Association between comorbid psychiatric and physical disorders and negative outcomes}

In this study, lifetime suicide attempt was associated with a two-fold increased risk of having psychiatric comorbidity. Findings from this study were in agreement with a previous study which established that suicide risk is highly elevated among people with both physical and psychiatric illness (comorbidity) due to the double burden of both conditions (109). Similarly, risky sexual behaviour was associated with a two-fold increased risk of having psychiatric comorbidity. Findings from this study are in agreement with a previous study which suggests that there is a clear association between risky sexual behaviour and common psychiatric disorders; sexual risk taking behaviour is also increased with psychiatric comorbidity, possible due to the nature of the illness and loss of insight (110).

This study has many strong points such as use of an adequate sample size due to pooling of multiple longitudinal panels, ability to assess prevalence of physical and psychiatric comorbidity, clustering of physical and psychiatric disorders plus establishing factors associated with comorbid physical and psychiatric disorders. However, there are some limitations to consider when interpreting the findings. This was cross-sectional study therefore it was not possible to determine the causal pathway between physical and psychiatric comorbidity; thus a longitudinal 
medRxiv preprint doi: https://doi.org/10.1101/2020.11.04.20225813; this version posted November 6, 2020. The copyright holder for this preprint (which was not certified by peer review) is the author/funder, who has granted medRxiv a license to display the preprint in perpetuity.

All rights reserved. No reuse allowed without permission.

study could be able to clearly establish such a causal pathway. Data on only a few physical morbidities were collected and considered in analysis; there is need to undertake a bigger study that focuses upon all physical and psychiatric comorbidities. Despite these limitations, to the best of our knowledge, this is the first study to establish the prevalence of physical and psychiatric comorbidity and associated risk factors among patients with severe mental illness attending Butabika National Psychiatric Referral Hospital and Masaka Regional Referral Hospital.

\section{Conclusion}

Based upon the findings established by this study, prevalence of comorbidity and associated risk factors among patients with severe mental illness (SMI) in rural and urban Uganda has become increasingly imperative. This issue may be particularly important for psychiatric practice in Uganda, given that most people with SMI in Uganda experience higher levels of socio-economic deprivation which is strongly and consistent associated with comorbidity (111). Given the central role of mental illness within the comorbidity continuum, it is our debate that psychiatrists, physicians, Clinical Psychologists, psychiatric clinical officers (PCO's), medical clinical officers (MCO’s), researchers and policy makers urgently need to discuss how best to develop and evaluate services that will improve physical, psychological and social outcomes for our patients. The emerging healthcare delivery models in Uganda should purpose to reduce fragmentation of care to help reduce the risks of preventable hospitalizations among mental healthcare beneficiaries with psychiatric comorbidity. 


\section{Materials and methods}

\section{Study design and site}

A cross-sectional study was undertaken among 1,201 individuals with SMI attending care at the out-patient departments (OPDs) at Butabika hospitals (central) and Masaka hospital

(southwestern) Uganda. To be eligible for the study, participants had to be adults over 18 years of age. Participants had to speak English or Luganda (the local language spoken in the study areas). Exclusion criteria were concurrent enrollment in another study), need of immediate medical attention, and unable to understand the study's assessment instruments.

\section{Measures}

The assessment battery comprised of a structured and standardised, locally translated psychosocial instruments (112-115). SMIs were established using the MINI International Neuropsychiatric Interview version 7.2. The tools were administered by trained psychiatric nurse / psychiatric clinical officer research assistants who assessed among others the psychiatric diagnosis. The variables reported in this paper include: (i) socio-demographic factors (study site, gender, age category, religion, socio-economic status, and marital status), (ii) psychosocial factors (social support, mental health stigma, childhood physical abuse, childhood sexual abuse, physical abuse in adulthood and sexual abuse in adulthood), (iii) psychiatric illness factors (family history of psychiatric illness, past depressive episode, past manic episode, past psychotic episode, lifetime suicide attempt), (iv) Psychotropic drugs (Antiparkinsonian medication, mood stabilizers, 1st generation neuroleptics, 2nd generation neuroleptics, Tri-cyclic anti-depressants, Selective Serotonin Reuptake Inhibitors) and (v) Maladaptive behaviour (alcohol use, use of tobacco, alcohol drinking problem, use of marijuana, use of khat). 
medRxiv preprint doi: https://doi.org/10.1101/2020.11.04.20225813; this version posted November 6, 2020. The copyright holder for this preprint (which was not certified by peer review) is the author/funder, who has granted medRxiv a license to display the preprint in perpetuity.

All rights reserved. No reuse allowed without permission.

\section{Statistical Analysis}

Analyses were done using Stata release Stata 15 (StataCorp, TX, USA)

Factors associated with each morbidity were found by fitting separate logistic regression models. A binary variable "psychiatric comorbidity" was generated having two or more of current/past depression or current/past mania or current/past psychosis

Firstly, descriptive statistics were described for socio-demographic characteristics and psychosocial factors. All models included study site (as a design variable), sex and age as a priori confounders. Potential additional socio-demographic characteristics included social economic status (8 household item scale), marital status, employment status, religion and level of education.

The prevalence and patterns of psychiatric illness factors, maladaptive behavior characteristics and morbidities were investigated at 95\% CI. Psychiatric and physical disorders were clustered to show different patterns of comorbidities.

Secondly, factors associated with having comorbid physical and psychiatric disorders among patients with severe mental illness were assessed by fitting multiple logistic regression models, adjusting for study site, age of the respondent and sex.

The impact of the morbidities with behavioral outcomes was investigated by fitting logistic regression models or ordinal logistic regression models. Logistic regression models were fitted for risky sexual behavior, symptom count on psychiatric outcomes and clinical outcomes (adherence to psychiatric medications and oral ART).

\section{Declarations section}

Ethics approval and consent to participate 
medRxiv preprint doi: https://doi.org/10.1101/2020.11.04.20225813; this version posted November 6, 2020. The copyright holder for this preprint

(which was not certified by peer review) is the author/funder, who has granted medRxiv a license to display the preprint in perpetuity.

All rights reserved. No reuse allowed without permission.

The study obtained ethical approvals from the Uganda Virus Research Institute's Research and

Ethics Committee (GC/127/19/10/612) and the Uganda National Council of Science and

Technology (HS 2337). Participants were given information about the study by trained study

psychiatric nurses and informed consent and assent sought before enrolment into the study.

Participants found to have a SMI were provided healthcare and supported at the out-patient departments (OPDs) of their respective hospitals.

\section{Consent to publish}

Not applicable.

\section{Availability of data and materials}

All data and materials in this manuscript, additional files and figures attached are freely available with no restrictions.

\section{Competing interests}

All authors declare that they have no competing interests.

\section{Funding}

This study was funded by MRC core funding to the Mental health project of MRC/UVRI and LSHTM under the headship of Professor Eugene Kinyanda to undertake the 'HIV clinical trials preparedness studies among patients with Severe Mental ILlnEss in HIV endemic Uganda (SMILE Study)'. 


\section{Authors' contributions}

RSM, WS, GZR, CB, KDG, AK, VP, MN and EK have made substantial contributions to conception, design, acquisition of data, drafting the manuscript, revising it critically and gave the final approval of this version to be published. WS did the analysis and interpretation of data. Each author participated sufficiently in this work and takes public responsibility for appropriate portions of the content.

\section{Acknowledgments}

The authors wish to thank the managers of the two study sites (Butabika National Psychiatric Referral Hospital and Masaka Regional Referral Hospital) for permitting the study to be conducted at their out-patient departments. The authors extend appreciation to the Medical Research Council, Uganda (MRC, Uganda) for funding and facilitating the study. Special gratitude is extended to the staff working at the two out-patient departments where the study was conducted. Appreciation is extended to the diligent work of research assistants. Gratitude is extended to the participants for their time and trust.

\section{Author's information}

${ }^{1}$ Mental Health Project, MRC/UVRI and LSHTM Uganda Research Unit, P. O. Box, 49, Entebbe, Uganda

${ }^{2}$ Butabika National Psychiatric Hospital, Kampala, Uganda

${ }^{8}$ Department of Mental health, School of Health Sciences, Soroti University, P. O. Box; 211, Soroti, Uganda

Tel: +256772 592504, +256446556\& +256702592504

E mail: richmpan@gmail.com \& Richard.Mpango@mrcuganda.org 


\section{References;}

1. World Health Organization. Addressing comorbidity between mental disorders and major noncommunicable diseases. Background technical report to support implementation of the WHO European Mental Health Action Plan 2013-2020 and the WHO European Action Plan for the Prevention and Control of Noncommunicable Diseases 2016-2025.

UN City, Marmorvej 51

DK-2100 Copenhagen $\varnothing$, Denmark: WHO Regional Office for Europe

2017.

2. Crump C, Winkleby MA, Sundquist K, Sundquist J. Comorbidities and mortality in persons with schizophrenia: a Swedish national cohort study. The American journal of psychiatry. 2013;170(3):324-33. 3. Henderson M, Hotopf M, Shah I, Hayes RD, Kuh D. Psychiatric disorder in early adulthood and risk of premature mortality in the 1946 British Birth Cohort. BMC psychiatry. 2011;11(1):37.

4. Lawrence D, Hancock KJ, Kisely S. The gap in life expectancy from preventable physical illness in psychiatric patients in Western Australia: retrospective analysis of population based registers. Bmj. 2013;346:f2539.

5. Laursen TM, Munk-Olsen T, Vestergaard M. Life expectancy and cardiovascular mortality in persons with schizophrenia. Curr Opin Psychiatry. 2012;25(2):83-8.

6. Smith DJ, Langan J, McLean G, Guthrie B, Mercer SW. Schizophrenia is associated with excess multiple physical-health comorbidities but low levels of recorded cardiovascular disease in primary care: cross-sectional study. BMJ open. 2013;3(4).

7. Scheen AJ, De Hert MA. Abnormal glucose metabolism in patients treated with antipsychotics. Diabetes \& metabolism. 2007;33(3):169-75.

8. Samsom JN, Wong AHC. Schizophrenia and Depression Co-Morbidity: What We have Learned from Animal Models. Front Psychiatry. 2015;6:13-.

9. Zhou C, Kong D, Zhu X, Wu W, Xue R, Li G, et al. Rethinking Schizophrenia and Depression Comorbidity as One Psychiatric Disorder Entity: Evidence From Mouse Model. Front Neurosci. 2020;14:115.

10. Tsai J, Rosenheck RA. Psychiatric comorbidity among adults with schizophrenia: a latent class analysis. Psychiatry research. 2013;210(1):16-20.

11. Zolezzi M, Abdulrhim S, Isleem N, Zahrah F, Eltorki Y. Medical comorbidities in patients with serious mental illness: a retrospective study of mental health patients attending an outpatient clinic in Qatar. Neuropsychiatr Dis Treat. 2017;13:2411-8.

12. Patel V, Chatterji S. Integrating Mental Health In Care For Noncommunicable Diseases: An Imperative For Person-Centered Care. Health affairs (Project Hope). 2015;34(9):1498-505.

13. Zulman DM, Asch SM, Martins SB, Kerr EA, Hoffman BB, Goldstein MK. Quality of care for patients with multiple chronic conditions: the role of comorbidity interrelatedness. Journal of general internal medicine. 2014;29(3):529-37.

14. Higashi T, Wenger NS, Adams JL, Fung C, Roland M, McGlynn EA, et al. Relationship between number of medical conditions and quality of care. The New England journal of medicine. 2007;356(24):2496-504.

15. Krein SL, Bingham CR, McCarthy JF, Mitchinson A, Payes J, Valenstein M. Diabetes treatment among VA patients with comorbid serious mental illness. Psychiatric services (Washington, DC). 2006;57(7):1016-21.

16. Kwarisiima D, Atukunda M, Owaraganise A, Chamie G, Clark T, Kabami J, et al. Hypertension control in integrated HIV and chronic disease clinics in Uganda in the SEARCH study. BMC Public Health. 2019;19(1):511 . 
medRxiv preprint doi: https://doi.org/10.1101/2020.11.04.20225813; this version posted November 6, 2020. The copyright holder for this preprint (which was not certified by peer review) is the author/funder, who has granted medRxiv a license to display the preprint in perpetuity.

All rights reserved. No reuse allowed without permission.

17. Centers for Medicare and Medicaid Services. Chronic Conditions Among Medicare Beneficiaries, Chartbook, 2012 Edition. . Baltimore2012.

18. Gladstone M, Lancaster GA, Umar E, Nyirenda M, Kayira E, van den Broek NR, et al. The Malawi Developmental Assessment Tool (MDAT): the creation, validation, and reliability of a tool to assess child development in rural African settings. PLoS Med. 2010;7(5):e1000273.

19. McCoy DC, Black MM, Daelmans B, Dua T. Measuring development in children from birth to age 3 at population level 2016.

20. World Health Organization. Meeting report: autism spectrum disorders and other developmental disorders: from raising awareness to building capacity: World Health Organization, Geneva, Switzerland 16-18 September 2013. World Health Organization. 2013.

21. Ajmera M, Wilkins TL, Findley PA, Sambamoorthi U. Multimorbidity, Mental Illness, and Quality of Care: Preventable Hospitalizations among Medicare Beneficiaries. International journal of family medicine. 2012;2012:823294.

22. Daré LO, Bruand P-E, Gérard D, Marin B, Lameyre V, Boumédiène F, et al. Co-morbidities of mental disorders and chronic physical diseases in developing and emerging countries: a meta-analysis. BMC Public Health. 2019;19(1):304.

23. Rukundo ZG, Nakasujja N, Musisi S. Psychiatric morbidity among physically ill patients in a Ugandan Regional Referral Hospital. African health sciences. 2013;13(1):82-6.

24. Doherty AM, Gaughran F. The interface of physical and mental health. Social psychiatry and psychiatric epidemiology. 2014;49(5):673-82.

25. Nadler S, Baker G, Morris K. Descartes's Dualism. Philosophical Books. 1997;38(3):157-69.

26. Ulzen TP, Hamilton $\mathrm{H}$. The nature and characteristics of psychiatric comorbidity in incarcerated adolescents. Can J Psychiatry. 1998;43(1):57-63.

27. Alfredo C, Leiva-Bianchi M, Serrano C, Teuber S, Cáceres C, Vitriol V. Factors Associated with Psychiatric Comorbidity in Depression Patients in Primary Health Care in Chile. Depression Research and Treatment. 2018;2018:1-9.

28. Buckley PF, Miller BJ, Lehrer DS, Castle DJ. Psychiatric comorbidities and schizophrenia. Schizophr Bull. 2009;35(2):383-402.

29. AmericanPsychiatricAssociation. 'Diagnostic and statistical manual of mental disorders - Text Revision'. IV-R, editor. Washington, DC: Author; 2000.

30. Laursen TM, Agerbo E, Pedersen CB. Bipolar disorder, schizoaffective disorder, and schizophrenia overlap: a new comorbidity index. The Journal of clinical psychiatry. 2009;70(10):1432-8.

31. Oreški I, Jakovljević M, Aukst-Margetić B, Orlić ZC, Vuksan-Ćusa B. Comorbidity and multimorbidity in patients with schizophrenia and bipolar disorder: similarities and differencies. Psychiatria Danubina. 2012;24(1):80-5.

32. UNAIDS. Uganda Country Report. 2018.

33. Maling S, Todd J, Van der Paal L, Grosskurth H, Kinyanda E. HIV-1 seroprevalence and risk factors for HIV infection among first-time psychiatric admissions in Uganda. AIDS care. 2011;23(2):171-8.

34. Lundberg P, Nakasujja N, Musisi S, Thorson AE, Cantor-Graae E, Allebeck P. HIV prevalence in persons with severe mental illness in Uganda: a cross-sectional hospital-based study. International journal of mental health systems. 2013;7:20-.

35. Uganda MoHo. 2013 Uganda HIV and AIDS Country Progress report. 2014.

36. International UMoHal. 2011 Uganda AIDS Indicator Survey: Key Findings. Calverton, Maryland, USA: MOHand ICF International, 2012.

37. Bank W. Uganda/ World Bank Development Indicators: Uganda - Prevalence Of Syphilis (\% Of Women Attending Antenatal Care). 2016.

38. Araújo MAL, de Freitas SCR, de Moura HJ, Gondim APS, da Silva RM. Prevalence and factors associated with syphilis in parturient women in Northeast, Brazil. BMC Public Health. 2013;13(1):206. 
medRxiv preprint doi: https://doi.org/10.1101/2020.11.04.20225813; this version posted November 6, 2020. The copyright holder for this preprint (which was not certified by peer review) is the author/funder, who has granted medRxiv a license to display the preprint in perpetuity.

All rights reserved. No reuse allowed without permission.

39. Lundberg P, Nakasujja N, Musisi S, Thorson AE, Cantor-Graae E, Allebeck P. Sexual Risk Behavior, Sexual Violence, and HIV in Persons With Severe Mental Illness in Uganda: Hospital-Based CrossSectional Study and National Comparison Data. American journal of public health. 2015;105(6):1142-8.

40. Guwatudde D, Mutungi G, Wesonga R, Kajjura R, Kasule H, Muwonge J, et al. The Epidemiology of Hypertension in Uganda: Findings from the National Non-Communicable Diseases Risk Factor Survey. PloS one. 2015;10(9):e0138991.

41. Woodhead C, Ashworth M, Schofield P, Henderson M. Patterns of physical co-/multi-morbidity among patients with serious mental illness: a London borough-based cross-sectional study. BMC family practice. 2014;15:117-.

42. Reilly S, Olier I, Planner C, Doran T, Reeves D, Ashcroft DM, et al. Inequalities in physical comorbidity: a longitudinal comparative cohort study of people with severe mental illness in the UK. BMJ open. 2015;5(12):e009010.

43. England PH. Hypertension prevalence estimates in England, 2017. London: Public Health England 2017.

44. Kirunda BE, Fadnes LT, Wamani H, Van den Broeck J, Tylleskär T. Population-based survey of overweight and obesity and the associated factors in peri-urban and rural Eastern Uganda. BMC Public Health. 2015;15(1):1168.

45. Correll CU, Druss BG, Lombardo I, O'Gorman C, Harnett JP, Sanders KN, et al. Findings of a U.S. national cardiometabolic screening program among 10,084 psychiatric outpatients. Psychiatric services (Washington, DC). 2010;61(9):892-8.

46. Ogden CL, Carroll MD, Kit BK, Flegal KM. Prevalence of obesity in the United States, 2009-2010. NCHS data brief. 2012(82):1-8.

47. Integrating the response to mental disorders and other chronic diseases in health care systems [press release]. Geneva: World Health Organization2014.

48. Academy of Medical Sciences, . Multimorbidity: a priority for global health research. United Kingdom: 2018.

49. Oni T, Unwin N. Why the communicable/non-communicable disease dichotomy is problematic for public health control strategies: implications of multimorbidity for health systems in an era of health transition. International health. 2015;7(6):390-9.

50. Assembly UNG. Prevention and control of non-communicable diseases. New York: United Nations, 2011.

51. Kabudula CW, Houle B, Collinson MA, Kahn K, Gómez-Olivé FX, Tollman S, et al. Socioeconomic differences in mortality in the antiretroviral therapy era in Agincourt, rural South Africa, 2001\&\#×2013;13: a population surveillance analysis. The Lancet Global Health. 2017;5(9):e924-e35.

52. Panagioti M, Stokes J, Esmail A, Coventry P, Cheraghi-Sohi S, Alam R, et al. Multimorbidity and Patient Safety Incidents in Primary Care: A Systematic Review and Meta-Analysis. PloS one. 2015;10(8):e0135947.

53. van Dooren FE, Nefs G, Schram MT, Verhey FR, Denollet J, Pouwer F. Depression and risk of mortality in people with diabetes mellitus: a systematic review and meta-analysis. PloS one. 2013;8(3):e57058.

54. M DEH, Correll CU, Bobes J, Cetkovich-Bakmas M, Cohen D, Asai I, et al. Physical illness in patients with severe mental disorders. I. Prevalence, impact of medications and disparities in health care. World Psychiatry. 2011;10(1):52-77.

55. Correll CU, Detraux J, De Lepeleire J, De Hert M. Effects of antipsychotics, antidepressants and mood stabilizers on risk for physical diseases in people with schizophrenia, depression and bipolar disorder. World Psychiatry. 2015;14(2):119-36.

56. Barnes PJ. Mechanisms of development of multimorbidity in the elderly. European Respiratory Journal. 2015;45(3):790. 
medRxiv preprint doi: https://doi.org/10.1101/2020.11.04.20225813; this version posted November 6, 2020. The copyright holder for this preprint (which was not certified by peer review) is the author/funder, who has granted medRxiv a license to display the preprint in perpetuity.

All rights reserved. No reuse allowed without permission.

57. Khansari N, Shakiba Y, Mahmoudi M. Chronic inflammation and oxidative stress as a major cause of age-related diseases and cancer. Recent patents on inflammation \& allergy drug discovery. 2009;3(1):73-80.

58. Pawelec G, Goldeck D, Derhovanessian E. Inflammation, ageing and chronic disease. Current opinion in immunology. 2014;29:23-8.

59. Stepanova M, Rodriguez E, Birerdinc A, Baranova A. Age-independent rise of inflammatory scores may contribute to accelerated aging in multi-morbidity. Oncotarget. 2015;6(3):1414-21.

60. Filipcic I, Šimunović Filipčić I, Grošić V, Bakija I, Šago D, Benjak T, et al. Patterns of chronic physical multimorbidity in psychiatric and general population2018.

61. Riva M, Bambra C, Curtis S, Gauvin L. Collective resources or local social inequalities? Examining the social determinants of mental health in rural areas. European journal of public health.

2011;21(2):197-203.

62. Melis R, Marengoni A, Angleman S, Fratiglioni L. Incidence and predictors of multimorbidity in the elderly: a population-based longitudinal study. PloS one. 2014;9(7):e103120-e.

63. Barnett K, Mercer SW, Norbury M, Watt G, Wyke S, Guthrie B. Epidemiology of multimorbidity and implications for health care, research, and medical education: a cross-sectional study. The Lancet. 2012;380(9836):37-43.

64. Allen J, Inder KJ, Lewin TJ, Attia J, Kelly BJ. Social support and age influence distress outcomes differentially across urban, regional and remote Australia: an exploratory study. BMC Public Health. 2012;12:928-.

65. Ghanotakis E, Peacock D, Wilcher R. The importance of addressing gender inequality in efforts to end vertical transmission of HIV. Journal of the International AIDS Society. 2012;15 Suppl 2(Suppl 2):17385-.

66. Mbonye M, Nalukenge W, Nakamanya S, Nalusiba B, King R, Vandepitte J, et al. Gender inequity in the lives of women involved in sex work in Kampala, Uganda. Journal of the International AIDS Society. 2012;15 Suppl 1(Suppl 1):1-9.

67. Ministry of Health M. UGANDA POPULATION-BASED HIV IMPACT ASSESSMENT UPHIA 20162017. Uganda Virus Research Institute, Uganda Bureau of Statistics, World Health Organization (WHO Uganda), and UNAIDS, 2017.

68. Igulot P, Magadi MA. Socioeconomic Status and Vulnerability to HIV Infection in Uganda: Evidence from Multilevel Modelling of AIDS Indicator Survey Data. AIDS research and treatment. 2018;2018:7812146.

69. Morris BJ, Krieger JN, Klausner JD. CDC's Male Circumcision Recommendations Represent a Key Public Health Measure. Glob Health Sci Pract. 2017;5(1):15-27.

70. Khumalo-Sakutukwa G, Lane T, van-Rooyen H, Chingono A, Humphries H, Timbe A, et al. Understanding and addressing socio-cultural barriers to medical male circumcision in traditionally noncircumcising rural communities in sub-Saharan Africa. Cult Health Sex. 2013;15(9):1085-100.

71. Awad SF, Sgaier SK, Lau FK, Mohamoud YA, Tambatamba BC, Kripke KE, et al. Could Circumcision of HIV-Positive Males Benefit Voluntary Medical Male Circumcision Programs in Africa? Mathematical Modeling Analysis. PloS one. 2017;12(1):e0170641-e.

72. Bunyasi EW, Coetzee DJ. Relationship between socioeconomic status and HIV infection: findings from a survey in the Free State and Western Cape Provinces of South Africa. BMJ open. 2017;7(11):e016232-e.

73. Kimani JK, Ettarh R, Ziraba AK, Yatich N. Marital Status and Risk of HIV Infection in Slum Settlements of Nairobi, Kenya: Results from a Cross-sectional Survey. African Journal of Reproductive Health / La Revue Africaine de la Santé Reproductive. 2013;17(1):103-13. 
medRxiv preprint doi: https://doi.org/10.1101/2020.11.04.20225813; this version posted November 6, 2020. The copyright holder for this preprint (which was not certified by peer review) is the author/funder, who has granted medRxiv a license to display the preprint in perpetuity.

All rights reserved. No reuse allowed without permission.

74. Campos LN, Guimarães MDC, Carmo RA, Melo APS, Oliveira HNd, Elkington K, et al. HIV, syphilis, and hepatitis $B$ and $C$ prevalence among patients with mental illness: a review of the literature. Cadernos de Saúde Pública. 2008;24:s607-s20.

75. Mutagoma M, Remera E, Sebuhoro D, \#xe9, Kanters S, Riedel DJ, et al. The Prevalence of Syphilis Infection and Its Associated Factors in the General Population of Rwanda: A National Household-Based Survey. Journal of Sexually Transmitted Diseases. 2016;2016:8.

76. HEALTH MO. Non-Communicable Disease Risk Factor Baseline Survey UGANDA 2014 REPORT. World Health Organisation, 2014.

77. Kavishe B, Biraro S, Baisley K, Vanobberghen F, Kapiga S, Munderi P, et al. High prevalence of hypertension and of risk factors for non-communicable diseases (NCDs): a population based crosssectional survey of NCDS and HIV infection in Northwestern Tanzania and Southern Uganda. BMC medicine. 2015;13:126-.

78. Kamkar MZ, Sanagoo A, Zargarani F, Jouybari L, Marjani A. Metabolic syndrome in patients with severe mental illness in Gorgan. J Nat Sci Biol Med. 2016;7(1):62-7.

79. Sainz J, Prieto C, Crespo-Facorro B. Sex differences in gene expression related to antipsychotic induced weight gain. PloS one. 2019;14(4):e0215477.

80. Bradshaw T, Mairs H. Obesity and Serious Mental III Health: A Critical Review of the Literature. Healthcare (Basel). 2014;2(2):166-82.

81. Ajayi IO, Adebamowo C, Adami HO, Dalal S, Diamond MB, Bajunirwe F, et al. Urban-rural and geographic differences in overweight and obesity in four sub-Saharan African adult populations: a multicountry cross-sectional study. BMC Public Health. 2016;16(1):1126.

82. Kirunda BE, Fadnes LT, Wamani H, Van den Broeck J, Tylleskär T. Population-based survey of overweight and obesity and the associated factors in peri-urban and rural Eastern Uganda. BMC Public Health. 2015;15:1168-.

83. Olaya B, Domenech-Abella J, Moneta MV, Lara E, Caballero FF, Rico-Uribe LA, et al. All-cause mortality and multimorbidity in older adults: The role of social support and loneliness. Experimental gerontology. 2017;99:120-6.

84. Mishra DK, Alreja S, Sengar KS, Singh AR. Insight and its relationship with stigma in psychiatric patients. Ind Psychiatry J. 2009;18(1):39-42.

85. Küey L. Stigma by health and mental health professionals in comorbid states. Ann Gen Psychiatry. 2010;9(Suppl 1):S41-S.

86. Tomasdottir MO, Sigurdsson JA, Petursson H, Kirkengen AL, Krokstad S, McEwen B, et al. Self Reported Childhood Difficulties, Adult Multimorbidity and Allostatic Load. A Cross-Sectional Analysis of the Norwegian HUNT Study. PloS one. 2015;10(6):e0130591.

87. Pavela G, Latham K. Childhood Conditions and Multimorbidity Among Older Adults. The Journals of Gerontology: Series B. 2015;71(5):889-901.

88. Skylstad V, Akol A, Ndeezi G, Nalugya J, Moland KM, Tumwine JK, et al. Child mental illness and the help-seeking process: a qualitative study among parents in a Ugandan community. Child and adolescent psychiatry and mental health. 2019;13(1):3.

89. Clarke K, Patalay P, Allen E, Knight L, Naker D, Devries K. Patterns and predictors of violence against children in Uganda: a latent class analysis. BMJ open. 2016;6(5):e010443.

90. UNICEF. Violence against Children in Uganda: Findings from a National Survey. Kampala, Uganda: Ministry of Gender, Labour and Social Development., 2015.

91. Devries KM, Child JC, Allen E, Walakira E, Parkes J, Naker D. School violence, mental health, and educational performance in Uganda. Pediatrics. 2014;133(1):e129-37.

92. Lundberg P, Johansson E, Okello E, Allebeck P, Thorson A. Sexual Risk Behaviours and Sexual Abuse in Persons with Severe Mental Illness in Uganda: A Qualitative Study. PloS one. 2012;7(1):e29748. 
medRxiv preprint doi: https://doi.org/10.1101/2020.11.04.20225813; this version posted November 6, 2020. The copyright holder for this preprint (which was not certified by peer review) is the author/funder, who has granted medRxiv a license to display the preprint in perpetuity.

All rights reserved. No reuse allowed without permission.

93. Meade CS, Kershaw TS, Hansen NB, Sikkema KJ. Long-term correlates of childhood abuse among adults with severe mental illness: adult victimization, substance abuse, and HIV sexual risk behavior. AIDS and behavior. 2009;13(2):207-16.

94. WHO. Addressing noncommunicable diseases and mental health: major challenges to sustainable development in the 21st century. "Mental health, poverty and development", July 20092009.

95. R K, al. e. Mental health stigma: What is being done to raise awareness and reduce stigma in South Africa? African journal of psychiatry. 2009(forthcoming).

96. Cross WHOalCotR, editor Mental Health Legislation \& Human Rights: Denied Citizens: Including the Excluded. Mental Health and Prisons; 2006; Geneva.

97. Ahn SW, Baek JH, Yang S-Y, Kim Y, Cho Y, Choi Y, et al. Long-term response to mood stabilizer treatment and its clinical correlates in patients with bipolar disorders: a retrospective observational study. International Journal of Bipolar Disorders. 2017;5(1):24.

98. Correll CU, Detraux J, De Lepeleire J, De Hert M. Effects of antipsychotics, antidepressants and mood stabilizers on risk for physical diseases in people with schizophrenia, depression and bipolar disorder. World psychiatry : official journal of the World Psychiatric Association (WPA). 2015;14(2):11936.

99. Bjekic $\mathrm{M}$, Vlajinac $\mathrm{H}$. [Effect of alcohol consumption on recurrence of venereal diseases]. Medicinski pregled. 2000;53(11-12):600-2.

100. Zenilman JM, Hook EW, 3rd, Shepherd M, Smith P, Rompalo AM, Celentano DD. Alcohol and other substance use in STD clinic patients: relationships with STDs and prevalent HIV infection. Sexually transmitted diseases. 1994;21(4):220-5.

101. Briasoulis A, Agarwal V, Messerli FH. Alcohol consumption and the risk of hypertension in men and women: a systematic review and meta-analysis. Journal of clinical hypertension (Greenwich, Conn). 2012;14(11):792-8.

102. Rehm J, Roerecke M. Cardiovascular effects of alcohol consumption. Trends in cardiovascular medicine. 2017;27(8):534-8.

103. Keck PE, McElroy SL. Bipolar disorder, obesity, and pharmacotherapy-associated weight gain. The Journal of clinical psychiatry. 2003;64(12):1426-35.

104. Tumwesigye NM, Mutungi G, Bahendeka S, Wesonga R, Swahn MH, Katureebe A, et al. Alcohol consumption, obesity and hypertension: Relationship patterns along different age groups in Uganda. bioRxiv. 2019:654251.

105. Hayatbakhsh R, J O'Callaghan M, Mamun A, Williams G, Clavarino A, Najman J. Cannabis Use and Obesity and Young Adults2010. 350-6 p.

106. Le Strat Y, Le Foll B. Obesity and Cannabis Use: Results From 2 Representative National Surveys. American Journal of Epidemiology. 2011;174(8):929-33.

107. Clark TM, Jones JM, Hall AG, Tabner SA, Kmiec RL. Theoretical Explanation for Reduced Body Mass Index and Obesity Rates in Cannabis Users. Cannabis Cannabinoid Res. 2018;3(1):259-71.

108. Alshagga MA, Alshawsh MA, Seyedan A, Alsalahi A, Pan Y, Mohankumar SK, et al. Khat (Catha edulis) and Obesity: A Scoping Review of Animal and Human Studies. Annals of Nutrition and Metabolism. 2016;69(3-4):200-11.

109. Qin P, Hawton K, Mortensen PB, Webb R. Combined effects of physical illness and comorbid psychiatric disorder on risk of suicide in a national population study. The British journal of psychiatry: the journal of mental science. 2014;204(6):430-5.

110. Ramrakha S, Caspi A, Dickson N, Moffitt TE, Paul C. Psychiatric disorders and risky sexual behaviour in young adulthood: cross sectional study in birth cohort. BMJ (Clinical research ed). 2000;321(7256):263-6. 
medRxiv preprint doi: https://doi.org/10.1101/2020.11.04.20225813; this version posted November 6, 2020. The copyright holder for this preprint (which was not certified by peer review) is the author/funder, who has granted medRxiv a license to display the preprint in perpetuity. All rights reserved. No reuse allowed without permission.

111. Langan J, Mercer SW, Smith DJ. Multimorbidity and mental health: can psychiatry rise to the challenge? British Journal of Psychiatry. 2018;202(6):391-3.

112. Kinyanda $\mathrm{E}$, Hjelmeland $\mathrm{H}$, Musisi $\mathrm{S}$. Negative life events associated with deliberate self-harm in an African population in Uganda. Crisis. 2005;26(1):4-11.

113. Kinyanda E, Hoskins S, Nakku J, Nawaz S, Patel V. Prevalence and risk factors of major depressive disorder in HIV/AIDS as seen in semi-urban Entebbe district, Uganda. BMC psychiatry. 2011;11:205.

114. Kinyanda E, Waswa L, Baisley K, D. M. Prevalence of severe mental distress and its correlates in a population-based study in rural south-west Uganda. BMC psychiatry. 2011;8(11):97.

115. Margolis PJ, Weintraub S. The revised 56-item CRPBI as a research instrument: Reliability and factor structure. . Journal of Clinical Psychology 1977;33:472-6. 


\section{Figure l: Conceptual framewrork on comorbidity in serere mental illness}

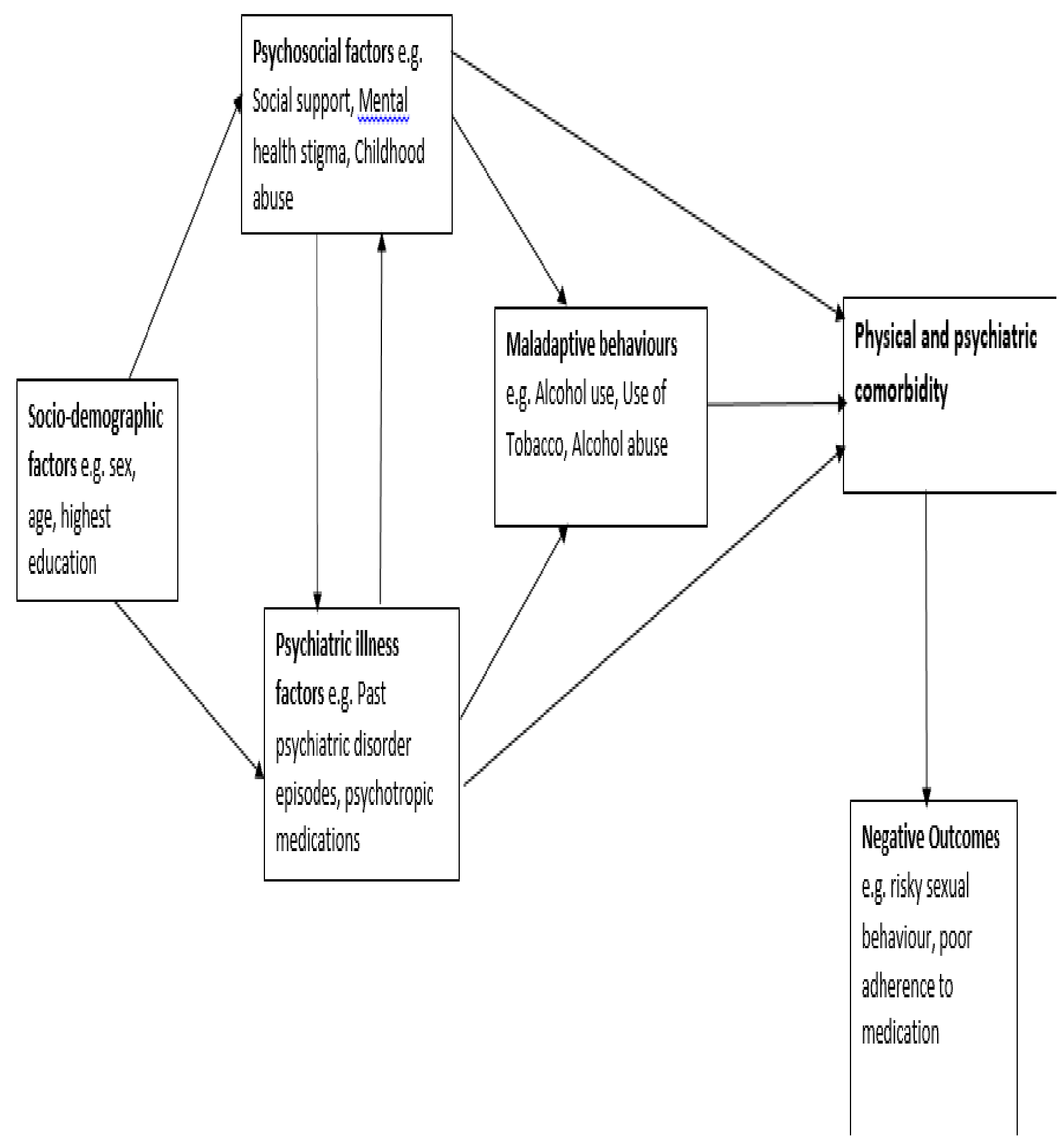




\section{Additional material}

Additional file 1: Table 1: Socio demographic and psychosocial characteristics

Additional file 2: Table 3: Association between socio-demographic factors and comorbid psychiatric and physical disorders

Additional file 3: Table 4: Psychosocial and psychiatric factors associated with comorbid psychiatric and physical disorders

Additional file 4: Table 5: Association between comorbid psychiatric and physical disorders and negative outcomes 